\title{
Maize hybrids with well-developed root system perform better under deficit supplemental irrigation
}

\author{
Mubshar Hussain ${ }^{1,2}$, Adnan Latif ${ }^{1}$, Waseem Hassan ${ }^{3}$, Shahid Farooq ${ }^{1,4}$, Sajjad Hussain ${ }^{5}$, \\ Shakeel Ahmad ${ }^{1}$ and Ahmad Nawaz ${ }^{3 *}$ \\ ${ }^{1}$ Department of Agronomy, Bahauddin Zakariya University, Multan, Pakistan. \\ ${ }^{2}$ School of Veterinary and Life Sciences, Murdoch University, 90 South Street, Murdoch, WA 6150, Australia. \\ ${ }^{3}$ College of Agriculture, Bahauddin Zakariya University, Bahadur Sub-Campus, Layyah, Pakistan. \\ ${ }^{4}$ Department of Agronomy, Faculty of Agricultural Sciences, Ghazi University, Dera Ghazi Khan, Pakistan. \\ ${ }^{5}$ Department of Horticulture, Bahauddin Zakariya University, Multan, Pakistan.
}

[Received: June 08, 2018 Accepted: August 16, 2018]

\begin{abstract}
Water deficiency has become a major issue threatening the sustainability of arable crops globally. This study was conducted to assess the effects of deficit supplemental irrigation (DSI) at different growth phases on the performance of different maize hybrids under semi-arid climate. The irrigations were skipped either at vegetative or reproductive stage, while a sufficient supplemental irrigation was taken as control in three maize hybrids i.e., $P$ 30Y87, S-6621 and P-30Y58. The DSI at both growth phases significantly hampered root length and proliferation, crop growth rate (CGR), leaf area index (LAI) and relative water contents (RWC). The DSI applied at both growth phases reduced the grain yield and yield related attributes, but DSI at reproductive stage was more lethal. Hybrid $P-30 Y 87$ performed better under different irrigation treatments due to better root system, crop allometry and other yield related traits compared to other hybrids while hybrid P-30Y58 recorded the lowest crop yield due to poor root system. The lateral roots had positive correlation with grains $\mathrm{cob}^{-1}$ and water use efficiency, while positive correlation among root length and grain weight and yield was observed under DSI at both growth phases. In conclusion, DSI at reproductive stage severely hampers the maize productivity; however maize productivity under deficit irrigation supply can potentially be improved to some extent by using maize hybrids with better root system. The moisture deficiency at reproductive stage proved more lethal for maize productivity, while maize hybrids with better root system potentially evaded the adverse effects of moisture deficits under semi-arid climate.
\end{abstract}

Keywords: Grain yield, Root system, Lateral roots, Deficit supplemental irrigation, Water use efficiency, Zea mays L.

\section{Introduction}

Agricultural drought is defined as the deficiency of sufficient moisture needed for normal plant growth to complete its life cycle (Hussain et al., 2018). The increased transpiration due to high ambient temperature and/or decreased water supply to root system leads to water deficit condition in crops (Farooq et al., 2012). Water deficiency hampers growth and development of crops, which ultimately decrease crop yield, more than any other abiotic stresses (Ullah et al., 2019). The decrease in growth and yield is linearly related to frequency and intensity of water deficit, both of which are unpredictable (Farooq et al., 2012, 2014). Water deficit severely reduces the productivity and WUE of arable crops by decreasing cell division and expansion, leaf size, elongation of stem and proliferation of roots (Hussain et al., 2008, 2009; Farooq et al., 2019). Water deficit also disturbs water relations of plants and uptake of nutrients, which results in less productivity and water use efficiency (Farooq et al., 2014, 2015, 2017; Hussain et al., 2016). The productivity of cereals is severely affected by increasing water deficit under arid and semi-arid regions of the world (Farooq et al., 2014; Ul-Allah et al., 2018).

Maize (Zea mays L.) is ranked third among cereals next to wheat (Triticum aestivum L.) and rice (Oryza sativa L.) and sown in broad range of soils and environmental conditions. Different factors affect the productivity of maize crop, including genetic characteristics of cultivars/hybrids, prevailing ecological and environmental conditions and production practices. Several negative effects of deficit irrigation to maize grain yield have been reported in numerous studies (Dağdelen et al., 2006; Khan et al., 2015; Tahir et al., 2019). The reduction in maize grain yield is reported to be the combined effect of reduced growth rate, decreased canopy cover, low accumulation of dry matter and less kernel numbers along with decreased weight (Dağdelen et al., 2006; Khan et al., 2015).

\footnotetext{
*Email: ahmadnawaz2006@gmail.com
} 
Maize is a $\mathrm{C}_{4}$ crop and efficiently utilizes available moisture. However, water deficit at any growth phase severely reduces the growth and productivity of maize crop (Hussain et al., 2013), but the sensitivity varies with the

\begin{tabular}{llll}
\multicolumn{4}{l}{ Table 1: Physico-chemical properties of the experimental site before initiation of experiment } \\
\hline \multicolumn{1}{l}{ Determination } & Unit & Value & Status \\
\hline Physical Analysis & $\%$ & & \\
Sand & $\%$ & 67.2 & \\
Silt & $\%$ & 17.2 & \\
Clay & $\%$ & 15.6 & \\
Textural class & Sandy clay loam & & \\
Chemical Analysis & & & \\
pH & & 7.8 & Very low \\
EC & $\mathrm{dS} \mathrm{m}-1$ & 1.39 & Very low \\
Organic matter & $\%$ & 0.50 & Low \\
Total nitrogen & $\%$ & 0.03 & Medium \\
Available phosphorus & $\mathrm{mg} \mathrm{kg}^{-1}$ & 10.00 & \\
Available potassium & $\mathrm{mg} \mathrm{kg}^{-1}$ & 115 & \\
\hline
\end{tabular}

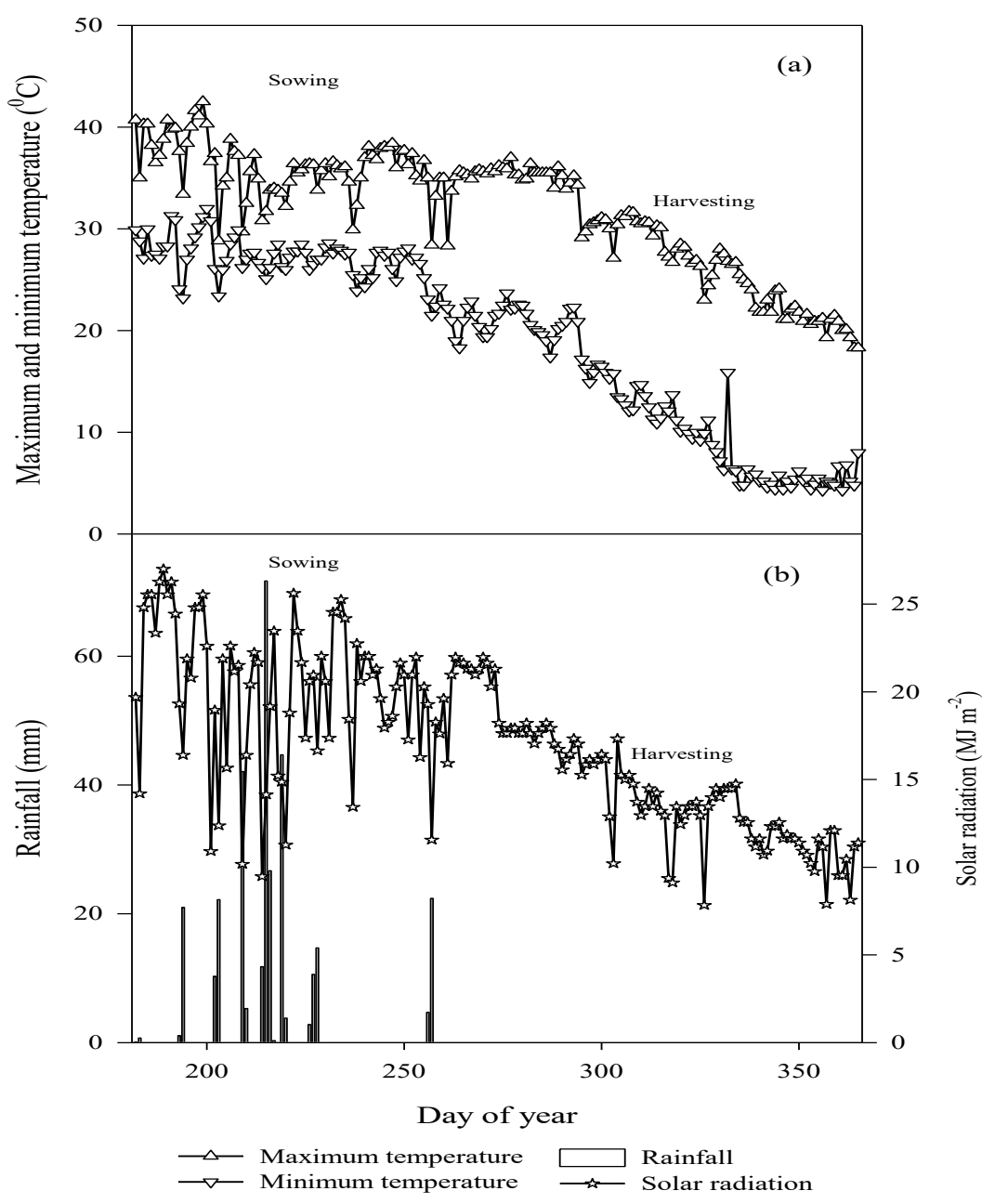

Figure 1: Daily maximum and minimum temperatures (a), rainfall and solar radiation (b) during the autumn season at experimental site. 
growth phase at which crop faces moisture deficiency (Grant et al., 1989). Maize is tolerant to water deficit in early growth stage, however severe deficit at any growth phase is lethal, which hampers crop productivity to great extent (Dhillon et al., 1995). The water deficiency at flowering or reproductive phase is most detrimental for maize and causes severe reduction in yield related traits (Hussain et al., 2013). The deficit water supply to maize crop at flowering stage adversely affects photosynthesis process, transport of assimilates and crops growth rate.

An established root-system can help crops to improve growth and productivity under deficit water and nutrient supply in soil. Therefore, the better root system has attracted the attention of crop breeders for enhancing crop productivity under normal and deficit water supply. The deficit water supply although hampers the root growth of tolerant genotypes, the effects are more severe in sensitive genotypes (Piro et al., 2003). Moreover, the root elongation is slowed down due to mechanical impedance offered by the soil under decreased water supply (Bengough et al., 2011), resulting in smaller roots. Thus plants explore less soil volume for acquiring moisture and nutrients due to the smaller roots (Chassot and Richner, 2002). The crop plants undergo several adaptations to water deficiency among which larger and welldeveloped root system is of prime importance. The longer and well-developed root system explore more soil volume resulting in improved water uptake, thus imparts tolerance to crop against water deficiency (Horst et al., 2001).

A massive genetic variation exists for tolerance to water deficiency in maize due to its polymorphic nature and cross pollination (Paterniani, 1990). Therefore, maize hybrids having high ability to perform better under water deficit environments are of great economic importance in today's agriculture (Rahman et al., 2004).

Due to the greater genetic variation in maize hybrids, it was hypothesized that the hybrids having deeper and more proliferated roots can potentially perform better under deficit water supply at different growth phases under arid areas. Hence, the study was aimed to evaluate the growth performance of diverse maize hybrids in terms of plant waterrelations, allometry of crop, root-system and productivity exposed to water deficit supplies at various growth phases under irrigated semi-arid environmental conditions.

\section{Materials and Methods Description of experimental site}

The research trial was carried out at the Research Area of the Department of Agronomy, Bahauddin Zakariya University, Multan, Pakistan $\left(71.43^{\circ} \mathrm{E} ; 30.2^{\circ} \mathrm{N}\right.$ and 122 meters from sea level) in the autumn crop season. The soil nutrient status of experimental site was evaluated just prior to initiation of the experiment. The physico-chemical properties of the soil are presented in Table 1. The research site lies in arid climate. The data of weather parameters for whole crop season is presented in Figure 1.

\section{Experiment information}

Three different hybrids, i.e., Pioneer-30Y87 (P-30Y87); Syngenta NK-6621 (S-6621); and Pioneer-30Y58 (P-30Y58) were grown under sufficient supplemental irrigation (SSI) throughout the growth period and deficit supplemental irrigation (DSI) either at vegetative (knee height) or reproductive stage. The P-30Y87 has stay green character, exhibits improved productivity in all types of weather conditions and is ready to harvest in approximately 110-115 days after seed emergence. Similarly, NK-6621 is well adapted to all environmental conditions, have high yield potential and gets ready for harvest in 110-125 days. Likewise, P-30Y58 is high yielding and matures in 110-120 days. The study was laid out in a randomized-completeblock-design with split-plot arrangement. The irrigation treatments were retained in main plots, while hybrids were randomized in sub-plots. The experiment had four replications with a $5 \mathrm{~m} \times 3 \mathrm{~m}$ net plot size of each experimental unit.

\section{Crop husbandry}

A pre-sowing flood irrigation $(10 \mathrm{~cm})$ was applied before seedbed preparation. The fine seed bed was prepared through cultivations twice with tractor-mountedcultivator along with planking after soil attained the workable moisture regime. The seeds were manually sown on well prepared ridges, keeping row-to-row and plant-toplant distance of 75 and $20 \mathrm{~cm}$, respectively. The field was supplied with $200 \mathrm{~kg} \mathrm{ha}^{-1} \mathrm{~N}$ and $150 \mathrm{~kg} \mathrm{ha}^{-1} \mathrm{P}$. The commercially available fertilizer urea $(46 \% \mathrm{~N})$ and diamonium phosphate $(46 \% \mathrm{P}$ and $18 \% \mathrm{~N})$ were used as source of $\mathrm{N}$ and $\mathrm{P}$, respectively. The whole amount of $\mathrm{P}$ was supplied at the time of sowing with seedbed preparation. The $\mathrm{N}$ was divided into two equal splits, the first split was applied at sowing with $\mathrm{P}$, while the second split was applied as fertigation with $1^{\text {st }}$ irrigation. To keep crop weed free, manual hoeing was done after $1^{\text {st }}$ irrigation and after that earthing-up was also done to keep the crop safe from lodging. The supplemental irrigation was skipped either at vegetative or reproductive stage to impose the moisture deficiency. The harvesting of the mature crop was manually after 110 days.

\section{Observations}

Five randomly selected plants of maize were uprooted with intensive care to avoid any damage to the roots at fortnight interval for observing root system of tested 
hybrids. The roots were washed carefully and allowed to air dry for some time to make the counting easier. The primary root length was measured with meter rod, total lateral roots were counted and measured. The fresh biomass of roots was recorded and then roots were dried for 72 hours at $\pm 70{ }^{\circ} \mathrm{C}$ and dry weight was recorded. The root-growth-rate (RGR) was calculated by following Hunt (1982). The periodic sampling was taken from 30 days after sowing (DAS) and terminated at crop harvest.

Leaf area was measure with the help of leaf area meter at fortnight intervals and converted into leaf area index (LAI) according to Watson (1947) . Moreover, crop growth rate (CGR) was estimated by following Hunt (1982). LAI and CGR measurements were also recorded at 30 DAS with 14 days interval and continued till harvesting.

The total plants present in every experimental plot at the time of harvest were calculated to get the plant population. Plant height $(\mathrm{cm})$ of ten randomly selected plants was measured with measuring tape and averaged. The number of cobs from 10 plants at random were counted and their lengths were measured to determine number of cobs plant $^{-1}$ and cob length $(\mathrm{cm})$, respectively. Total number of grains from 10 randomly selected cobs were separated manually, counted and averaged to record total grains $\operatorname{cob}^{-1}$.
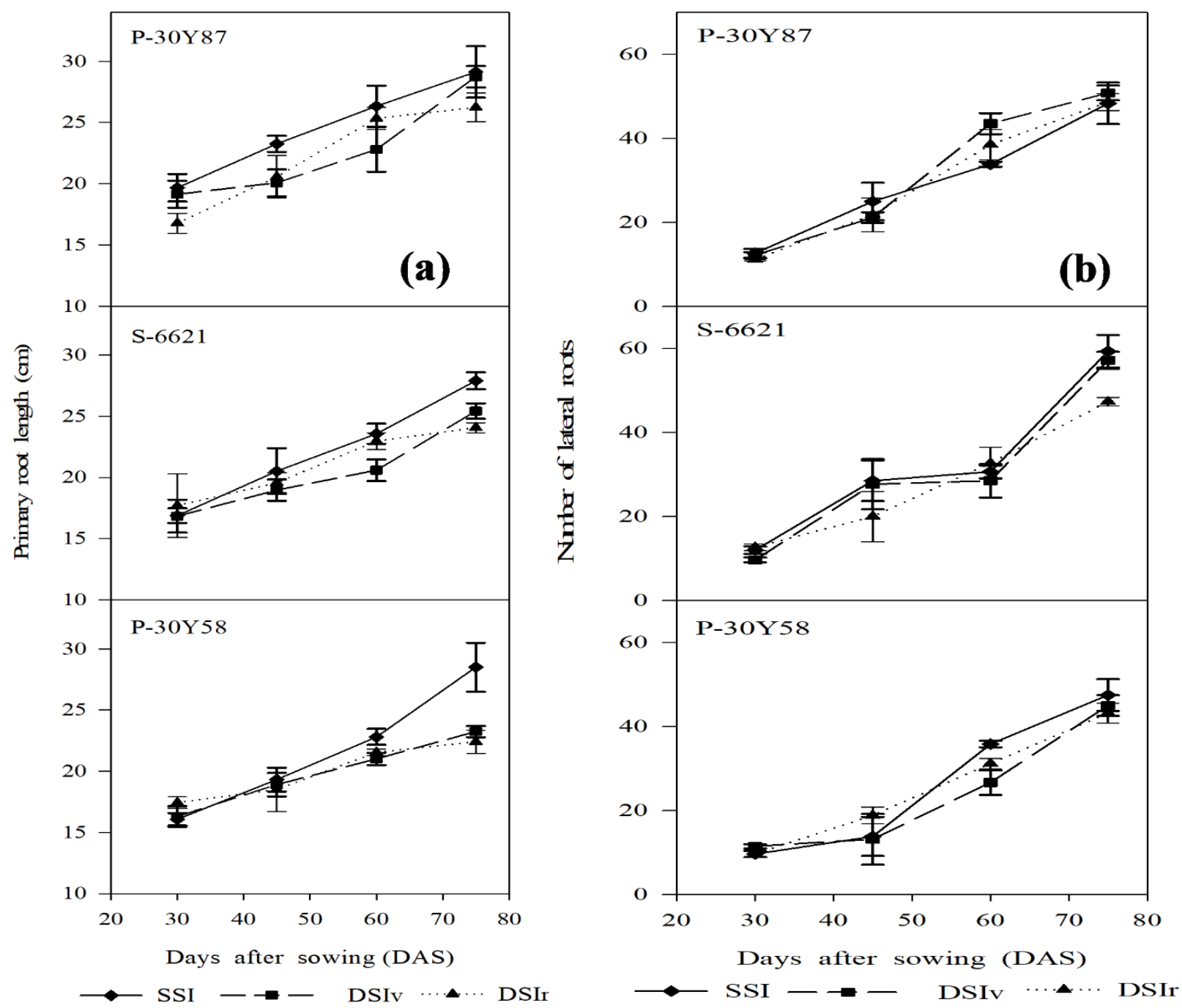

SSI $=$ Sufficient supplemental irrigation throughout the crop season, DSIv $=$ Deficit supplemental irrigation at vegetative stage, DSIr $=$ Deficit supplemental irrigation at reproductive stage.

Figure 2. Effect of SSI and DSI at vegetative and reproductive stage on primary root length (a) and number of lateral roots (b) of different maize hybrids \pm S.E. 

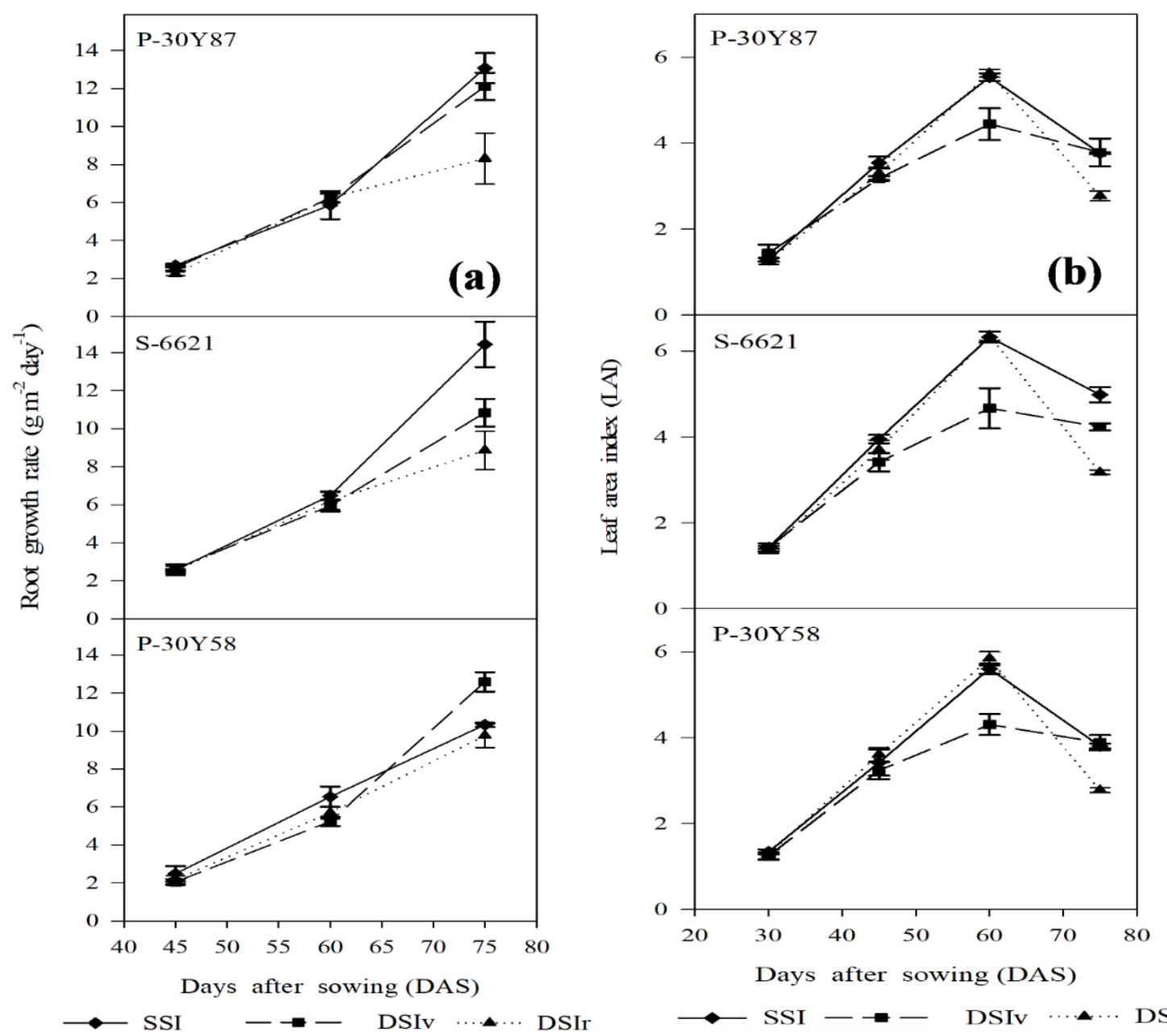

SSI = Sufficient supplemental irrigation throughout crop season, DSIv $=$ Deficit supplemental irrigation at vegetative stage, DSIr $=$ Deficit supplemental irrigation at reproductive stage

Figure 3. Effect of SSI and DSI at vegetative and reproductive stage on root growth rate (a) and leaf area index (b) of different maize hybrids \pm S.E.,

Five random samples of 1000-grains from each seed-lot obtained after threshing every experimental unit were selected, weighed on a sensitive electronic scale and averaged to record 1000-grain weight (g). All surviving plants at harvest maturity were manually harvested, sundried, threshed manually to determine grain yield into $t \mathrm{ha}^{-1}$. The biomass of the sun-dried plants was recorded by weighing (without cobs) with the help of portable springbalance $\left(\mathrm{t} \mathrm{ha}^{-1}\right)$. The biomass of plants and grain yield were added to get biomass yield into $t \mathrm{ha}^{-1}$. Harvest index (HI) was calculated as the ratio of grain yield to biological biomass and stated as percentage.

The relative water contents (RWC) of leaves were determined by harvesting the $3^{\text {rd }}$ leaf from apex of two randomly selected plants from every experimental unit. The leaves were detached from the plants close to lamina base, conserved in polyethylene bags and immediately shifted to laboratory. The fresh-weight (FW) of the detached leaves was determined within 2 hours. After weighing, leaves were immersed in distilled water for 18 hours at room temperature. Then, leaves were removed from the water, surface-dried within two layers of filter paper and weighed to record turgid weight (TW). Then the leaves were dried in an oven at $70 \pm 5^{\circ} \mathrm{C}$ for 72 hours and dry weight (DW) was recorded. The following equation was used to compute the leaf relative water contents (LRWC),

$\operatorname{LRWC}(\%)=\frac{(\mathrm{FW}-\mathrm{DW})}{(\mathrm{TW}-\mathrm{DW})} \times 100$

Water-use-efficiency (WUE) $\left(\mathrm{kg} \mathrm{m}^{-3}\right)$ was documented by following Viets (1962) as under; 
WUE $=\frac{\text { Grain yield }}{\text { Water applied }}$

Water applied included the amount of irrigation and rainfall received by the crop throughout the growing season.

\section{Statistical analysis}

The data were statistically analyzed in two steps. Firstly, the normality tests were conducted for each measured parameter. The data showing non-normal distribution was normalized using $\log$ transformation. Secondly, the significance in the collected data was tested by Fisher's analysis of variance (ANOVA) and where ANOVA indicated significant differences, means were separated by using least significant post-hoc test at 5\% probability (Steel et al., 1997). The data was graphically presented by using SigmaPlot version 13 (Systat Software Inc).

\section{Results}

A gradual increase in root system traits like main root length, number of lateral roots and root growth rate (RGR) was recorded for all maize hybrids as the growth period progressed (Figures $2 \mathrm{a}, 2 \mathrm{~b}$ and $3 \mathrm{a}$ ). The DSI at vegetative stage at 60 DAS and reproductive stages at 75 DAS considerably decreased primary root length with varying degree compared to SSI, while DSI had no significant effect on root length at 30 and 45 DAS (Figure 2a). Among maize hybrids, P-30Y87 produced longer roots both under SSI and DSI, while DSI resulted in drastic reduction of root length of hybrid P-30Y58 (Figure 2a). The DSI either at vegetative or reproductive stage resulted in slight increase in number of lateral roots of P-30Y87. However, DSI decreased the number of lateral roots of other two hybrids, and DSI at reproductive stage resulted in the highest reduction of root length in hybrid S-6621 at 75 DAS (Figure 2b). The RGR of hybrids P-30Y87 and S-6621 was reduced at 75 DAS by DSI at both growth stages, while DSI at reproductive stage proved more lethal in this regard. The DSI at vegetative stage reduced the RGR of hybrid S-30Y58 at 60 DAS, but improved RGR even more than SSI at 75 DAS under the same treatment (Figure 3a).

The LAI and CGR were gradually increased up to 60 DAS, then started to decline (Figures $3 b$ and $4 a$ ). The LAI of all tested hybrids was equally decreased by DSI either at vegetative or reproductive stage. The maximum reduction in LAI was observed at 60 and 75 DAS in all hybrids compared with SSI (Figure 3b). However, DSI either at vegetative or reproductive stages reduced CGR of all maize hybrids, but in dissimilar fashion in contrast to LAI (Figure 4a). The DSI at vegetative stage decreased the CGR of hybrid P-30Y87 at 60 DAS, while improved at 75 DAS. The
DSI at vegetative stage resulted in low CGR of hybrid S6621 at 60 DAS, while DSI at reproductive stage resulted in low CGR for hybrid P-30Y58 at 75 DAS (Figure 4a).

Different yield associated attributes i.e., cob length, grains $\mathrm{cob}^{-1}$ and 1000-grain weight were significantly affected by DSI, while had no effects on plant population at harvest and cobs plant ${ }^{-1}$ (Table 2). The cob length, grains $\mathrm{cob}^{-1}$ and 1000-grain weight were notably decreased under DSI at reproductive stage compared with SSI (Table 2). There were significant differences among maize hybrids regarding plant population, cob length and 1000-grain weight, whereas no differences were observed for cobs plant $^{-1}$ and grains cob ${ }^{-1}$ (Table 2).

The highest plant population was observed for hybrid P-30Y87 compared to other hybrids (Table 2). Similarly, hybrids P-30Y87 and P-30Y58 produced longer cobs than S-6621. However, higher 1000-grain weight was observed in P-30Y87 and S-6621 than P-30Y58 (Table 2). Regarding interactions among maize hybrids and irrigation treatments, cob length and 1000-grain were significantly affected and differences among plant population, cobs plant ${ }^{-1}$ and grains $\mathrm{cob}^{-1}$ were non-significant (Table 2). The hybrids P-30Y87 and P-30Y58 with SSI produced larger sized cobs, while the smallest cobs were produced by hybrid S-6621 under DSI at reproductive stage (Table 2). Similarly, the highest and the lowest 1000-grain weight was recorded in hybrid P-30Y58 with SSI and DSI at vegetative and reproductive stage, respectively (Table 2).

Plant height, grain yield and biological yield were severely reduced by DSI either at vegetative or reproductive stage compared with SSI, while DSI at reproductive stage proved more detrimental (Table 3). However, harvest index (HI) remained unaffected by DSI (Table 3). The maize hybrid, P-30Y87 produced a better overall yield compared with other hybrids included in the study (Table 3 ). Moreover, plant height and HI were also higher in P-30Y87 compared with other tested hybrids, while there were no differences among hybrids for biological yield (Table 3). In interactions among irrigation treatments and hybrids; all hybrids with SSI produced taller plants, while smaller plants were observed in maize hybrids S-6621 and P-30Y58 receiving DSI at reproductive stage (Table 3). The hybrid P30 Y87 produced the highest grain and biological yields with SSI, while hybrid P-30Y58 with DSI at reproductive stage produced the lowest grain and biological yields (Table 3).

The higher leaf RWC were observed in hybrid P-30Y87 at 45 DAS with DSI, while the RWC were lowered by DSI at reproductive stage at 75 DAS (Figure $4 \mathrm{~b}$ ). The lower RWC were observed in hybrid S-6621 at 60 and 75 DAS with SSI and DSI at reproductive stage, respectively (Figure 4b). The WUE was significantly affected by maize hybrids, 
Table 2: Effect of DSI and SSI at vegetative and reproductive growth stages on plant population and yield related attributes of different maize hybrids

\begin{tabular}{|c|c|c|c|c|c|}
\hline Treatments & $\begin{array}{l}\text { Plant population } \\
\left(\mathbf{m}^{-2}\right)\end{array}$ & $\begin{array}{l}\text { Cob length } \\
(\mathrm{cm})\end{array}$ & $\begin{array}{l}\text { Number of cobs } \\
\text { per plant }\end{array}$ & $\begin{array}{l}\text { Number of grains } \\
\text { per cob }\end{array}$ & $\begin{array}{l}\text { 1000-grain } \\
\text { weight (g) }\end{array}$ \\
\hline \multicolumn{6}{|l|}{ Irrigation (I) } \\
\hline $\mathrm{I}_{1}$ & 4.74 & $19.16 \mathrm{a}$ & 2.11 & $465 \mathrm{a}$ & $258 \mathrm{a}$ \\
\hline $\mathrm{I}_{2}$ & 4.71 & $17.22 \mathrm{~b}$ & 1.78 & $444 \mathrm{a}$ & $223 \mathrm{~b}$ \\
\hline $\mathrm{I}_{3}$ & 4.68 & $17.22 \mathrm{~b}$ & 1.78 & $379 \mathrm{~b}$ & $180 \mathrm{c}$ \\
\hline $\begin{array}{l}\text { LSD value } \\
(p \leq 0.05)\end{array}$ & NS & 0.94 & NS & 22.11 & 12.15 \\
\hline \multicolumn{6}{|c|}{ Maize hybrids (H) } \\
\hline $\mathrm{H}_{1}$ & $5.02 \mathrm{a}$ & $17.63 \mathrm{a}$ & 1.78 & 440 & 229 a \\
\hline $\mathrm{H}_{2}$ & $4.66 \mathrm{~b}$ & $17.10 \mathrm{~b}$ & 2.00 & 418 & $222 \mathrm{ab}$ \\
\hline $\mathrm{H}_{3}$ & $4.38 \mathrm{~b}$ & $17.62 \mathrm{a}$ & 1.89 & 429 & $210 b$ \\
\hline $\begin{array}{l}\text { LSD value } \\
(p \leq 0.05)\end{array}$ & 0.32 & 0.38 & NS & NS & 17.72 \\
\hline \multicolumn{6}{|c|}{ Interaction $(\mathbf{I} \times \mathbf{H})$} \\
\hline $\mathrm{I}_{1} \mathrm{H}_{1}$ & 5.00 & $19.12 \mathrm{ab}$ & 1.78 & 482 & $262 \mathrm{~b}$ \\
\hline $\mathrm{I}_{1} \mathrm{H}_{2}$ & 4.90 & $18.69 \mathrm{~b}$ & 2.45 & 451 & $206 \mathrm{c}$ \\
\hline $\mathrm{I}_{1} \mathrm{H}_{3}$ & 4.40 & $19.66 \mathrm{a}$ & 2.11 & 461 & $306 \mathrm{a}$ \\
\hline $\mathrm{I}_{2} \mathrm{H}_{1}$ & 4.90 & $17.62 \mathrm{c}$ & 2.00 & 439 & $240 \mathrm{~b}$ \\
\hline $\mathrm{I}_{2} \mathrm{H}_{2}$ & 4.50 & $17.22 \mathrm{~cd}$ & 1.78 & 437 & $275 \mathrm{a}$ \\
\hline $\mathrm{I}_{2} \mathrm{H}_{3}$ & 4.57 & $16.82 \mathrm{de}$ & 1.78 & 456 & $155 \mathrm{e}$ \\
\hline $\mathrm{I}_{3} \mathrm{H}_{1}$ & 5.00 & $16.16 \mathrm{f}$ & 1.78 & 400 & $185 \mathrm{c}-\mathrm{e}$ \\
\hline $\mathrm{I}_{3} \mathrm{H}_{2}$ & 4.43 & $15.39 \mathrm{~g}$ & 1.78 & 366 & $186 \mathrm{~cd}$ \\
\hline $\mathrm{I}_{3} \mathrm{H}_{3}$ & 4.53 & $16.39 \mathrm{ef}$ & 1.78 & 370 & $170 \mathrm{de}$ \\
\hline $\begin{array}{l}\text { LSD value } \\
(p \leq 0.05)\end{array}$ & NS & 0.66 & NS & NS & 30.68 \\
\hline
\end{tabular}

Means following same letters, within a column, were statistically $(p \leq 0.05)$ not different for individual and interactive effects.

$\mathrm{I}_{1}=$ Sufficient supplemental irrigation (SSI) throughout crop season, $\mathrm{I}_{2}=$ Deficit supplemental irrigation $(\mathrm{DSIv})$ at vegetative stage, $\mathrm{I}_{3}=$ Deficit supplemental irrigation (DSIr) at reproductive stage, $\mathrm{H}_{1}=\mathrm{P}-30 \mathrm{Y} 87, \mathrm{H}_{2}=\mathrm{S}-6621, \mathrm{H}_{3}=\mathrm{P}-30 \mathrm{Y} 58$, NS = non-significant.

irrigation treatments and their interactions (Table 3). The higher WUE was observed under SSI and DSI at vegetative stage compared with DSI at reproductive stage (Table 3). The hybrid P-30Y87 used water more efficiently compared with P-30Y58 (Table 3). Regarding interactive effect, hybrid P-30Y87 with SSI and hybrid S-6621 with DSI at vegetative stage had higher WUE, while hybrid P-30Y58 resulted in lower WUE under DSI at reproductive stage (Table 3).

The number of lateral roots had significant positive correlation with grains $\mathrm{cob}^{-1}$ and WUE only under DSI at vegetative and reproductive stage. Similarly, root length exhibited a positive correlation with 1000 -grain weight and grain yield under DSI at different growth stages. Moreover, root length was also significantly correlated with grain yield and WUE in maize hybrids.

\section{Discussion}

The results of the present study indicated that yield and productivity of maize hybrids was reduced by DSI either at vegetative or reproductive stage, while DSI at reproductive stage proved more drastic in this regard. All three hybrids differed in performance due to their inherent genetic makeup. The highest and lowest grain yield was observed in maize hybrids P-30Y87 and P-30Y58 with SSI and DSI at reproductive stage, respectively (Table 3 ). The reduced cell division and enlargement leading to disturbed enzyme activities, loss of turgor along with reduced energy supply are the possible reasons for a poor root system under DSI at vegetative and reproductive stages (Hussain et al., 2009, 2018). The decrease in root length and density of maize under deficit moisture availability has also been reported by Ogawa et al. (2005). The well-developed root system of hybrid P-30Y87 is possibly due to superior and better genetic makeup compared to other hybrids. The more availability of assimilates under sufficient moisture availability might be the reason of higher LAI and CGR of hybrid P-30Y87 (Figures 3b and 4a) which substantially lead to higher RGR.

The shallow and poor root system (Figures $2 \mathrm{a}$ and $2 \mathrm{~b}$ ) under lower/deficit moisture availability results in lower 
Table 3: Effect of DSI and SSI at vegetative and reproductive stages on plant height, yield, harvest index and water use efficiency of different maize hybrids

\begin{tabular}{|c|c|c|c|c|c|c|}
\hline Treatments & $\begin{array}{l}\text { Plant } \\
\text { (cm) }\end{array}$ & height & $\begin{array}{l}\text { Grain yield } \\
\left(\mathrm{t} \mathrm{ha}^{-1}\right)\end{array}$ & $\begin{array}{l}\text { Biological yield } \\
\left(\mathrm{t} \mathrm{ha}^{-1}\right)\end{array}$ & $\begin{array}{l}\text { Harvest index } \\
(\%)\end{array}$ & $\begin{array}{l}\text { WUE } \\
\left(\mathrm{kg} \mathrm{m}^{-3}\right)\end{array}$ \\
\hline \multicolumn{7}{|l|}{ Irrigation (I) } \\
\hline $\mathrm{I}_{1}$ & $231 \mathrm{a}$ & & $8.92 \mathrm{a}$ & $28.38 \mathrm{a}$ & 31.43 & $2.61 \mathrm{a}$ \\
\hline $\mathrm{I}_{2}$ & $213 b$ & & $7.14 \mathrm{~b}$ & $21.87 \mathrm{~b}$ & 32.65 & $2.78 \mathrm{a}$ \\
\hline $\mathrm{I}_{3}$ & $181 \mathrm{c}$ & & $6.09 \mathrm{c}$ & $18.37 \mathrm{c}$ & 33.15 & $2.40 \mathrm{~b}$ \\
\hline LSD value $(p \leq 0.05)$ & 9.61 & & 0.42 & 0.70 & NS & 0.11 \\
\hline \multicolumn{7}{|l|}{ Maize hybrids (H) } \\
\hline $\mathrm{H}_{1}$ & $217 \mathrm{a}$ & & $8.12 \mathrm{a}$ & 23.56 & $34.47 \mathrm{a}$ & $2.92 \mathrm{a}$ \\
\hline $\mathrm{H}_{2}$ & $205 \mathrm{~b}$ & & $7.35 \mathrm{~b}$ & 23.31 & $31.53 \mathrm{~b}$ & $2.64 \mathrm{~b}$ \\
\hline $\mathrm{H}_{3}$ & $203 \mathrm{~b}$ & & $6.71 \mathrm{c}$ & 21.91 & $30.63 \mathrm{~b}$ & $2.41 \mathrm{c}$ \\
\hline LSD value $(p \leq 0.05)$ & 6.01 & & 0.44 & NS & 1.80 & 0.14 \\
\hline \multicolumn{7}{|l|}{ Interaction $(\mathbf{I} \times \mathbf{H})$} \\
\hline $\mathrm{I}_{1} \mathrm{H}_{1}$ & $235 \mathrm{a}$ & & $10.30 \mathrm{a}$ & $32.79 \mathrm{a}$ & $31.41 \mathrm{bc}$ & $3.17 \mathrm{a}$ \\
\hline $\mathrm{I}_{1} \mathrm{H}_{2}$ & $225 \mathrm{ab}$ & & $8.15 \mathrm{~b}$ & $24.46 \mathrm{c}$ & $33.32 \mathrm{~b}$ & $2.47 \mathrm{c}$ \\
\hline $\mathrm{I}_{1} \mathrm{H}_{3}$ & $235 \mathrm{a}$ & & $8.08 \mathrm{~b}$ & $27.93 \mathrm{~b}$ & $28.93 \mathrm{c}$ & $2.47 \mathrm{c}$ \\
\hline $\mathrm{I}_{2} \mathrm{H}_{1}$ & $223 b$ & & $7.42 \mathrm{~b}$ & $19.95 \mathrm{de}$ & $37.19 \mathrm{a}$ & $2.89 \mathrm{~b}$ \\
\hline $\mathrm{I}_{2} \mathrm{H}_{2}$ & $217 \mathrm{~b}$ & & $7.52 \mathrm{~b}$ & $23.55 \mathrm{c}$ & $31.93 \mathrm{bc}$ & $2.96 \mathrm{ab}$ \\
\hline $\mathrm{I}_{2} \mathrm{H}_{3}$ & $198 \mathrm{c}$ & & $6.53 \mathrm{c}$ & $22.12 \mathrm{~cd}$ & $29.52 \mathrm{c}$ & $2.54 \mathrm{c}$ \\
\hline $\mathrm{I}_{3} \mathrm{H}_{1}$ & $194 \mathrm{c}$ & & $6.46 \mathrm{c}$ & $17.95 \mathrm{e}$ & $35.99 \mathrm{ab}$ & $2.54 \mathrm{c}$ \\
\hline $\mathrm{I}_{3} \mathrm{H}_{2}$ & $172 \mathrm{~d}$ & & $6.35 \mathrm{c}$ & $21.45 \mathrm{~d}$ & $29.60 \mathrm{c}$ & $2.50 \mathrm{c}$ \\
\hline $\mathrm{I}_{3} \mathrm{H}_{3}$ & $177 \mathrm{~d}$ & & $5.55 \mathrm{~d}$ & $15.68 \mathrm{f}$ & $35.40 \mathrm{ab}$ & $2.15 \mathrm{~d}$ \\
\hline LSD value $(p \leq 0.05)$ & 10.41 & & 0.77 & 2.17 & 3.12 & 0.25 \\
\hline
\end{tabular}

Means following same letters, within a column, were statistically ( $p \leq 0.05)$ not different for individual and interactive effects.

$\mathrm{I}_{1}=$ Sufficient supplemental irrigation (SSI) throughout crop season, $\mathrm{I}_{2}=$ Deficit supplemental irrigation (DSIv) at vegetative stage, $\mathrm{I}_{3}=$ Deficit supplemental irrigation (DSIr) at reproductive stage, $\mathrm{H}_{1}=\mathrm{P}-30 \mathrm{Y} 87, \mathrm{H}_{2}=\mathrm{S}-6621, \mathrm{H}_{3}=\mathrm{P}-30 \mathrm{Y} 58$, NS $=$ non-significant.

uptake of moisture and nutrients as roots explore lesser volume of the soil (Khan et al., 2012), which ultimately results in lower LAI. Among three hybrids, P-30Y87 developed a longer and better root system, which helped in maintaining higher LAI (Figures 2a, 2b and 3a), accumulated more nutrients and used available moisture more efficiently (Khan et al., 2012; Hussain et al., 2013). The CGR is linearly associated with the amount of intercepted light, while the more leaf area and higher leaf area index help to intercept more solar radiations (Subedi and Ma, 2005). The higher CGR of P-30Y87 in the current study under sufficient moisture supply was probably due to better LAI (Figure 3b). The better CGR due to higher LAI in maize has also been reported in earlier studies (Rahman et al., 2004). The genetic differences for maize hybrids for producing differential LAI and CGR are also well explained by Akram et al. (2010).

Moisture deficiency either at vegetative or reproductive stage significantly hampered grain output of maize, while moisture deficiency at reproductive stage proved more lethal. Many earlier studies have also reported the decrease in maize grain yield due to deficit moisture supplies (Çakir, 2004; Xin et al., 2011). The significant cut in yield associated traits such as cob size, grains row $^{-1}$ and 1000- grain weight was the principal reason for a drastic yield decline under DSI at reproductive stage in the current study (Table 3). The pollen sterility due to DSI at reproductive stage might be the reason for the decrease in number of grains $\mathrm{cob}^{-1}$, as pollen sterility leads to lower grain set. Moreover, the susceptible genotypes to moisture deficiency allocate lesser assimilates towards aboveground strata at earlier growth stages, which lead to poor grain set at the later stages of crop growth (Richards, 2006). Similarly, 18 and $40 \%$ decrease in grains $\operatorname{cob}^{-1}$ of maize under DSI at vegetative and reproductive stages has been reported by Sah and Zamora (2005) compared with ample moisture availability. Nonetheless, the poorly developed and shallow root system (Figs. 2a and 2b) might have resulted in lower accumulation of nutrients, ion imbalances, lower transport of solute from root to shoot which resulted in the hampering of yield related traits and lower grain output. Moreover, the positive significant correlation of the root system with cob length, grain weight and grain yield further strengthened the argument. The lower biological yield under DSI might be the result of lower accumulation of photo-assimilates due to decreased LAI and CRG (Figures 3b and 4a).

The maize hybrid P-30Y87 produced greater grain yield under ample water supply due to better yield associated 

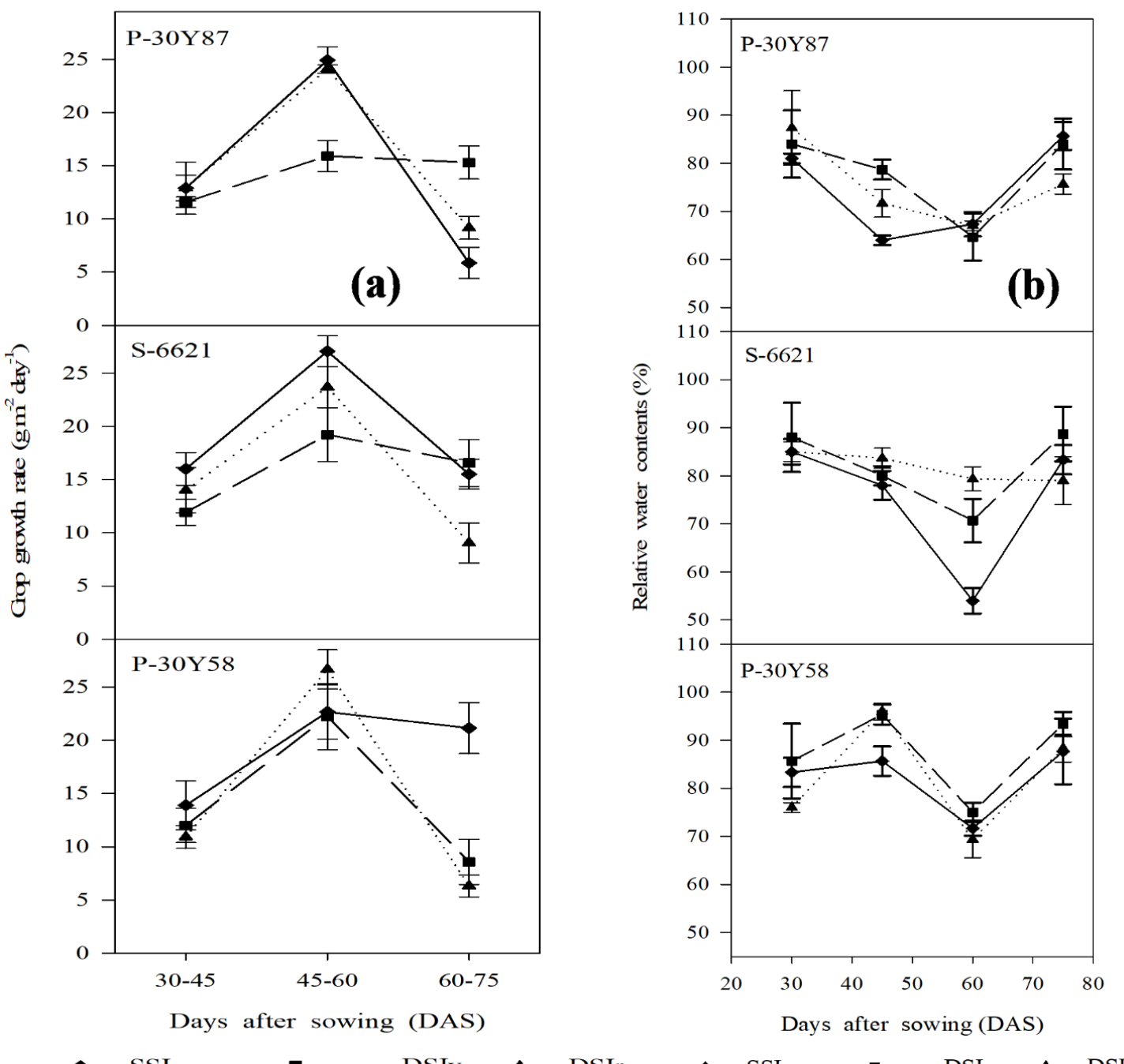

SSI $=$ Sufficient supplemental irrigation throughout the crop season, DSIv $=$ Deficit supplemental irrigation at vegetative stage, DSIr $=$ Deficit supplemental irrigation at reproductive stage

\section{Figure 4. Effect of SSI and DSI at vegetative and reproductive stage on crop growth rate (a) and relative water} contents (b) of different maize hybrids \pm S.E.

traits such as cob length, grains $\operatorname{cob}^{-1}$ and 1000-grain weight (Table 3). The longer and well-developed root system helped the hybrid P-30Y87 to fetch more water and nutrients which enabled it in better assimilate partitioning and improved solute transport from root to shoot. Moreover, the root length exhibited significant correlations with grain yield, which indicates that long and welldeveloped root system helped the P-30Y87 for producing superior grain yield. Contrastingly, poorly developed and shallow root system of hybrid P-30Y58 resulted in lower nutrient and water uptake, which ultimately reduced its grain yield due to poor yield related attributes. Although, the hybrids included in the study showed a varying response for grain yield, ample reports are available indicating that moisture deficiency severely reduces the grain yield of maize (Monneveux et al., 2006; Xin et al., 2011). The differences in maize hybrids in the current study are thought to be the result of their inherent genetic makeup.

The WUE was severely reduced by DSI due to reductions in grain yield (Table 3). Due to the poorly developed and shallow root system under DSI at reproductive stage, maize hybrids were unable to utilize the available water efficiently which lead to lower WUE 
under DSI at reproductive stage. The WUE of maize under SSI and DSI at vegetative stage were statistically similar. Although maize with SSI produced higher grain yield, it used more water to produce that amount of grain yield. Therefore, the amount of increase in yield per unit of water applied was similar in SSI and DSI at vegetative stage. The higher WUE under DSI at vegetative stage in sunflower has been reported by Hussain et al. (2009). The higher WUE of hybrid P-30Y87 is the direct result of welldeveloped root system and better utilization of available moisture as longer roots explored more volume of the soil compared to the hybrids with shallow and poorly developed root system (Table 3).

\section{Conclusion}

The deficit moisture supply hampered the root system leading to lower productivity, but moisture deficit at reproductive stage proved more drastic. Similarly, different maize hybrids also had varying responses under sufficient and deficit moisture supplies. The highest and the least grain yield and WUE was noted for hybrids P30 Y87 and P-30Y58 due to well-developed and poor developed root systems, respectively. The moisture deficiency at reproductive proved more lethal for maize productivity, while the maize hybrids with better root system potentially evaded the adverse effects of moisture deficits under semi-arid climate.

\section{References}

Akram, M., M.Y. Ashraf, E.A. Waraich, M. Hussain, N. Hussain and A.R. Mallahi. 2010. Performance of autumn planted maize (Zea mays L.) hybrids at various nitrogen levels under salt affected soils. Soil and Environment 29:23-32.

Bengough, A.G., B.M. McKenzie, P.D. Hallett and T.A. Valentine. 2011. Root elongation, water stress, and mechanical impedance: a review of limiting stresses and beneficial root tip traits. Journal of Experimental Botany 62:59-68.

Chassot, A. and W. Richner. 2002. Root characteristics and phosphorus uptake of maize seedlings in a bilayered soil. Agronomy Journal 94:118-127.

Dagdelen, N., E. Y1lmaz, F. Sezgin and T. Gurbuz. 2006. Water-yield relation and water use efficiency of cotton (Gossypium hirsutum L.) and second crop corn (Zea mays L.) in western Turkey. Agricultural Water Management 82:63-85.

Dhillon, B.S., H.S. Thind, V.K. Saxena, R.K. Sharma and N.S. Malhi. 1995. Tolerance to excess water stress and its association with other traits in maize. Crop Improvement 22:24-28.
Farooq, M., M. Hussain, A. Wahid and K.H.M. Siddique. 2012. Drought stress in plants: an overview. In: Plant responses to drought stress. R. Aroca (ed.), Springer, 133.

Farooq, M., M. Hussain and K.H.M. Siddique. 2014. Drought stress in wheat during flowering and grainfilling periods. Critical Reviews in Plant Sciences 33:331-349.

Farooq, S., M. Shahid, M.B. Khan, M. Hussain and M. Farooq. 2015. Improving the productivity of bread wheat by good management practices under terminal drought. Journal of Agronomy and Crop Science 201:173-188.

Farooq, S., M. Hussain, K. Jabran, W. Hassan, M.S. Rizwan and T.A. Yasir. 2017. Osmopriming with $\mathrm{CaCl}_{2}$ improves wheat (Triticum aestivum L.) production under water-limited environments. Environmental Science and Pollution Research 24:13638-13649.

Farooq, M., M. Hussain, S. Ul-Allah and K.H.M. Siddique. 2019. Physiological and agronomic approaches for improving water-use efficiency in crop plants. Agricultural Water Management 219:95-108.

Grant, R.F., B.S. Jackson, J.R. Kiniry, and G.F. Arkin. 1989. Water deficit timing effects on yield components in maize. Agronomy Journal 81:61-65.

Horst, W.J., M. Kamh, J.M. Jibrin and V.O. Chude. 2001. Agronomic measures for increasing $\mathrm{P}$ availability to crops. Plant and Soil 237:211-223.

Hunt, R. 1982. Plant growth analysis. Institute of Terrestrial Ecology. 4-7.

Hussain, M., S. Farooq, W. Hasan, S. Ul-Allah, M. Tanveer, M. Farooq and A. Nawaz. 2018. Drought stress in sunflower: Physiological effects and its management through breeding and agronomic alternatives. Agricultural Water Management 201:152-167.

Hussain, M., M. Waqas-ul-Haq, S. Farooq, K. Jabran and M. Farooq. 2016. The impact of seed priming and row spacing on the productivity of different cultivars of irrigated wheat under early season drought. Experimental Agriculture 52:477-490.

Hussain, M., M.A. Malik, M. Farooq, M.B. Khan, M. Akram and M.F. Saleem. 2009. Exogenous glycine betaine and salicylic acid application improves water relations, allometry and quality of hybrid sunflower under water deficit conditions. Journal of Agronomy Crop Science 195:98-109.

Hussain, M., M.A. Malik, M. Farooq, M.Y. Ashraf and M.A. Cheema. 2008. Improving drought tolerance by exogenous application of glycine betaine and salicylic acid in sunflower. Journal of Agronomy and Crop Science 194:193-199. 
Hussain, M., W. Bashir, S. Farooq and A. Rehim. 2013. Root development, allometry and productivity of maize hybrids under terminal drought sown by varying method. International Journal of Agriculture and Biology 15:1243-1250.

Khan, M.B., F. Yousaf M. Hussain, M.W. Haq, D.J. Lee and M. Farooq. 2012. Influence of planting methods on root development, crop productivity and water use efficiency in maize hybrids. Chilean Journal of Agricultural Research 72:556-563.

Khan, M.B., M. Hussain, A. Raza, S. Farooq and K. Jabran. 2015. Seed priming with $\mathrm{CaCl}_{2}$ and ridge planting for improved drought resistance in maize. Turkish Journal of Agriculture Forestry 39:193-203.

Monneveux, P., C. Sanchez, D. Beck and G.O. Edmeades 2006. Drought tolerance improvement in tropical maize source populations. Crop Science 46:180-191.

Ogawa, A., C. Kawashima and A. Yamauchi. 2005. Sugar accumulation along the seminal root axis, as affected by osmotic stress in maize: a possible physiological basis for plastic lateral root development. Plant Production Science 8:173-180.

Paterniani, E. 1990. Maize breeding in the tropics. Critical Reviews in Plant Sciences 9:125-154.

Piro, G., M.R. Leucci, K. Waldron and G. Dalessandro. 2003. Exposure to water stress causes changes in the biosynthesis of cell wall polysaccharides in roots of wheat cultivars varying in drought tolerance. Plant Science 165:559-569.

Rahman, M.U., S. Gul and I. Ahmad. 2004. Effects of water stress on growth and photosynthetic pigments of corn (Zea mays L.) cultivars. International Journal of Agriculture and Biology 6:652-655.

Richards, R.A. 2006. Physiological traits used in the breeding of new cultivars for water-scarce environments. Agricultural Water Management 80:197211.

Sah, S.K. and O.B. Zamora. 2005. Effect of water deficit at vegetative and reproductive stages of hybrid, open pollinated variety and local maize (Zea mays L.). Journal of the Institute of Agriculture and Animal Science 26:37-42.
Steel, R.G.D., J.H. Torrie and D.A. Dickey. 1997. Principles and Procedures of Statistics: A Biological Approach. McGraw-Hill. New York. 400-428.

Subedi, K.D. and B.L. Ma. 2005. Ear position, leaf area, and contribution of individual leaves to grain yield in conventional and leafy maize hybrids. Crop Science 45:2246-2257.

Tahir, M., U. Khalid, M.B. Khan, M. Shahid, I. Ahmad, M. Akram, M. Ijaz, M. Hussain, A.B.U. Farooq, M.A. Naeem and N. Ahmad. 2019. Auxin and 1aminocyclopropane-1-carboxylate deaminase activity exhibiting rhizobacteria improved maize quality and productivity under drought conditions. International Journal of Agriculture and Biology 21:943-954.

Ul-Allah, S., M. Iqbal, S. Maqsood, M. Naeem, M. Ijaz, W. Ashfaq and M. Hussain. 2018. Improving the performance of bread wheat genotypes by managing irrigation and nitrogen under semi-arid conditions. Archives of Agronomy and Soil Science 64:1678-1689.

Ullah, S., M. Ashraf, H.N. Asghar, Z. Iqbal and R. Ali. 2019. Plant growth promoting rhizobacteria-mediated amelioration of drought in crop plants. Soil and Environment 38:1-20.

Viets, F.G. 1962. Fertilizers and the efficient use of water. Advances in Agronomy 14:223-264.

Watson, D.J. 1947. Comparative physiological studies on the growth of field crops: Variation in net assimilation rate and leaf area between species and varieties and within and between years. Annals of Botany 11:41-76.

Xin, Z., L.G. Mel, L. Shiqing, L. Shengxiu and L.I.A.N.G. Zongsuo. 2011. Modulation of plant growth, water status and antioxidantive system of two maize (Zea mays L.) cultivars induced by exogenous glycine betaine under long term mild drought stress. Pakistan Journal of Botany 43:1587-1594. 